\title{
One step towards bioremediating a heavily polluted river: Metagenomic insights on the function of microbial community
}

Luz Breton-Deval ${ }^{* 1}$, Ayixon Sanchez-Reyes ${ }^{1}$, Alejandro Sánchez-Flores ${ }^{2}$, Katy Juárez ${ }^{1}$, Patricia Mussali-Galante ${ }^{3}$,

${ }^{1}$ Instituto de Biotecnología, Universidad Nacional Autónoma de México, Avenida Universidad 2001, Colonia Chamilpa, Cuernavaca, Morelos 62210, México

¿Unidad Universitaria de Secuenciación Masiva y Bioinformática, Instituto de Biotecnología, Universidad Nacional Autónoma de México, Cuernavaca, México ${ }^{3}$ Laboratorio de Investigaciones Ambientales, Centro de Investigación en Biotecnología, Universidad Autónoma del Estado de Morelos, Avenida Universidad 1001, Colonia Chamilpa, 62209. Cuernavaca, Morelos, México

\section{${ }^{*}$ Corresponding author:}

Dr. Luz Breton-Deval

E-mail: Izbreton@ibt.unam.mx

Instituto de Biotecnología, Universidad

Nacional Autónoma de México, Avenida

Universidad 2001, Colonia Chamilpa,

Cuernavaca, Morelos 62210, México. 


\section{One step towards bioremediating a heavily polluted river: Metagenomic} insights on the function of microbial community

\section{ABSTRACT}

6 The objective of this study is to understand the functional potential of the microbial community related to bioremediation activity and its relationship with

8 the pollution of each site to enhance the future design of more accurate bioremediation processes. Water samples were collected at four sampling sites

10 along the Apatlaco River (S1-S4), and a whole metagenome shotgun sequencing was performed to know and understand the microbial community involved in bioremediation. Additionally, HMMER was used for searching sequence homologs related to PET and polystyrene biodegradation and metal transformation in Apatlaco River metagenomes. The Apatlaco River is characterized by the presence of a broad spectrum of microorganisms with the metabolic potential to carry out bioremediation activities. Every site along the Apatlaco River has a particular community to perform bioremediation activities.

The first site S1 has Thiomonas, Polaromonas, Pedobacter, and Myroides, S2 has Pedobacter, Myroides, Pseudomonas and Acinetobacter, S3, Thiomonas, Myroides, Pseudomonas, Acinetobacter and Aeromonas; S4, Thiomonas, Myroides and Pseudomonas, Thauera.

22 Furthermore, every site is rich in specific enzymes such as S1 has dioxygenase and dehydrogenase, which can degrade Catechol, Biphenyl, Naphthalene, and Phthalate. While, S2 and S3 are rich in dioxygenase and decarboxylating dehydrogenases to degrade Toluene, Fluorobenzoate, Xylene, 26 Phenylpropanoate, and Phenol. S3 also has monooxygenases which degrade Benzene, and all the earlier mentioned enzymes were also found at S4. 
Keywords: metagenomics, water pollution, river, superficial water, bioremediation

\section{Introduction}

Rivers are complex systems closely and continuously connected to terrestrial ecosystems. The connection creates dynamic riverine ecosystems that experience a high flux of nutrients (Y. W. Zhao et al., 2019). Typically, the amount of Carbon $(C)$ that rivers transport to the ocean is a small fraction of the total amount of $\mathrm{C}$ that rivers receive from terrestrial ecosystems. Some of the remaining $\mathrm{C}$ is returned to the atmosphere in the form of $\mathrm{CO}_{2}$, while another part is stored in river sediment (Wang et al., 2016). Besides, some C is also incorporated into the trophic chain. However, at present, rivers transport unusually high amounts of $\mathrm{C}$ and other compounds as a result of human activities in addition to the normal flow of $\mathrm{C}$ from terrestrial ecosystems (Peters et al., 2019).

A polluted river is a complex ecosystem given the different chemical substances that flow into the waterway such as heavy metals, hydrocarbons, high amounts of organic matter as well as chlorinated, nitroaromatic and organophosphate compounds (Y. Zhao et al., 2019). The biogeochemistry of polluted rivers is unbalanced because the energy captured to support either biosynthesis or 50 respiration is more than the system requires; additionally, toxic compounds modify the microbial community (Li et al., 2013).

52 As a result, it is necessary to address pollution from a practical and affordable approach; a way to achieve this is via bioremediation. Bioremediation is a 
54 process used to reduce environmental contaminants by employing enzymes, microorganism, plants, microbial metabolites, or any bioproduct (Arora and Bae,

2014; Suthersan, 1999). However, a lot of uncertainty continues to surround some bioremediation strategies due to the lack of understanding of the specific microbes that are vital to performing the transformation of pollutants resulting from unspecific strategies that employ consortia of bacteria to carry out bioremediation projects (Dvořák et al., 2017). Only 1\% of microorganisms are cultivable, and the community consortia have more microbes than the number of microorganisms that can be measured with traditional techniques (Ghosh and Bhadury, 2018). In contrast, Next-Generation sequencing such as the Whole Metagenome Shotgun (WMS) approaches to discover the total genomic content and microbial functions of the sample, which permits an understanding of the biochemical interactions of the microbial population with the surrounding environment without the limitations of the culture-based techniques. Besides, a resolution is higher than the universal 16S marker gene profiles (González-Toril and Aguilera, 2018; Techtmann and Hazen, 2016).

Research into the microbial ecology of impacted sites, including the complete genome sequences of diverse microorganisms and additionally their functions and the factors that influence these functions, could be useful to determine the gene pool of enzymes necessary for the degradation of the pollutant (Liu et al., 2018; Megharaj et al., 2011). Furthermore, this knowledge could help to select the best approach to eliminate pollution at the site. In some cases, the polluted site may include species that tolerate the contaminant, although this species is not dominant due to the lack of an appropriate carbon source (Techtmann and 78 Hazen, 2016). In other contexts, there may not be a microorganism naturally 
available with the metabolic capacity to process the pollutant however a more effective microorganism could be added to the polluted location (Uhrynowski et al., 2017). A clear understanding of these characteristics of the river assists in the development of an effective bioremediation strategy to reverse the impact of pollution.

84 The Apatlaco River is located in central México in the state of Morelos. It is $63 \mathrm{~km}$ in length and provides water to 10 state districts and an average of 2 millions of people (IMTA, 2008). The river receives 321 wastewater discharges, of which $49 \%$ come from industrial activities, $42 \%$ from the domestic sector and just $9 \%$ from farming (Fig. 1). As a result of these discharges, the contamination of the river is heterogeneous (Moeller-Chávez et al., 2004). Therefore, it is necessary to find a feasible solution to treat the river that is an essential key in regional development.

92 Therefore, the objective of this study is to understand the functional potential of the microbial community related with bioremediation activity and its relationship with the Apatlaco's pollution to enhance the future design of more accurate bioremediation processes.

\section{Materials and Methods}

\subsection{Study site, sample collection, and chemical parameters measured}

The water samples were collected at 4 sampling sites along the Apatlaco River 100 (S1-S4), where S1 is clean, (-99.26872, 18.97372) and S2 (-99.2187, 18.83), S3 $(-99.23337,18.78971)$ and S4 $(-99.18278,18.60914)$ have different level of 
collected and then combined to form a single sample for molecular analyses. for further processing.

106

$\boldsymbol{\Delta}$ INDUSTRIAL

* DOMESTIC

AGRICULTURAL SUB-BASIN RIVER APATLACO
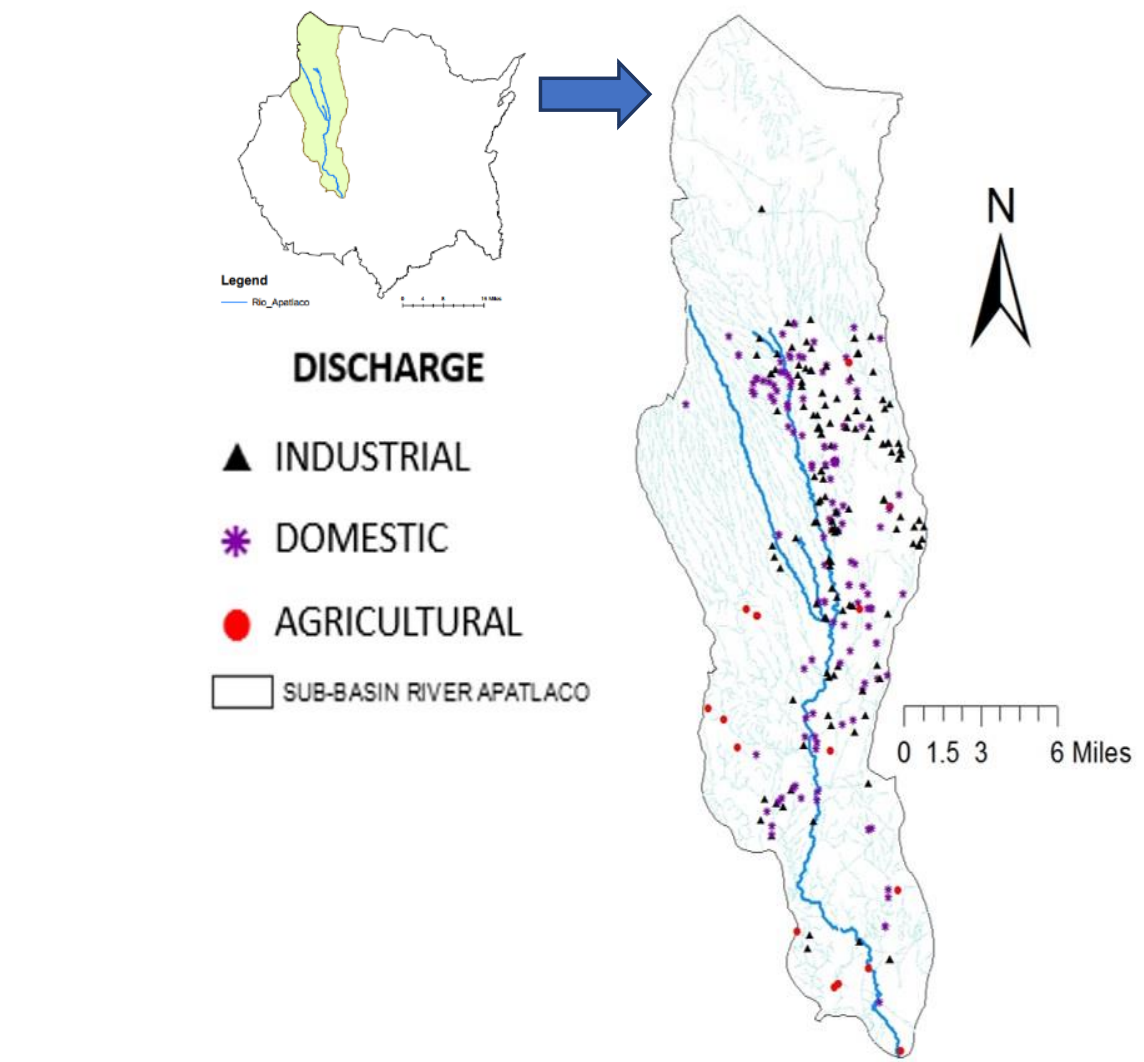

Figure 1 The Apatlaco River, where purple, black and red dots are the different discharges of domestic, industrial and agro origin respectively.

HANNA multi parametric instrument DR900 was used to measure the following parameters: dissolved oxygen (DO), Total nitrogen (TN), total phosphorus (TP).

124 The chemical oxygen demand (COD) was determined with the colorimetric method using HACH digester DRB200 and the DR900. , and total dissolved solids (TDS) were measured according to Standard Methods. 
Table 1 Measurements of physicochemical parameters along the Apatlaco

River

\begin{tabular}{rcccc}
\hline Pollutants & S1 & S2 & S3 & S4 \\
\hline $\mathrm{COD}(\mathrm{mg} / \mathrm{L})$ & $80 \pm 9.36$ & $270 \pm 23.35$ & $480 \pm 31$ & $110 \pm 16$ \\
$\mathrm{TN}(\mathrm{mg} / \mathrm{L})$ & $6 \pm 1.48$ & $31 \pm 6.74$ & $38 \pm 5.78$ & $45 \pm 6.45$ \\
$\mathrm{DO}(\mathrm{mg} / \mathrm{L})$ & $7 \pm 0.59$ & $4 \pm 0.38$ & $2 \pm 1.19$ & $7 \pm 1.98$ \\
$\mathrm{TP}(\mathrm{mg} / \mathrm{L})$ & $0.77 \pm 0.22$ & $9 \pm 2.65$ & $16 \pm 2.45$ & $9 \pm 1.47$ \\
$\mathrm{TDS}(\mathrm{mg} / \mathrm{L})$ & $62 \pm 1.77$ & $206 \pm 9.75$ & $299 \pm 10.35$ & $756 \pm 20.67$ \\
$\mathrm{Temp}\left({ }^{\circ} \mathrm{C}\right)$ & $17 \pm 1.56$ & $22 \pm 1.10$ & $23 \pm 1.21$ & $26 \pm 2.25$ \\
$\mathrm{Zn}(\mathrm{mg} / \mathrm{L})$ & $0.20 \pm 0.02$ & $0.16 \pm 0.02$ & $0.20 \pm 0.02$ & $0.13 \pm 0.01$ \\
$\mathrm{Cd}(\mathrm{mg} / \mathrm{L})$ & $0.07 \pm 0.02$ & $0.16 \pm 0.01$ & $0.19 \pm 0.01$ & $0.16 \pm 0.01$ \\
$\mathrm{~Pb}(\mathrm{mg} / \mathrm{L})$ & $3.95 \pm 0.22$ & $2.53 \pm 0.27$ & $2.24 \pm 0.08$ & $4.35 \pm 0.15$ \\
$\mathrm{Cu}(\mathrm{mg} / \mathrm{L})$ & $0.99 \pm 0.04$ & $0.46 \pm 0.02$ & $1.15 \pm 0.06$ & $0.88 \pm 0.03$ \\
$\mathrm{Mn}(\mathrm{mg} / \mathrm{L})$ & $<0.0015$ & $<0.0015$ & $<0.0015$ & $<0.0015$ \\
$\mathrm{Cr}(\mathrm{mg} / \mathrm{L})$ & $<0.003$ & $<0.003$ & $<0.003$ & $<0.003$ \\
\hline & & & &
\end{tabular}

Five water samples from Apatlaco River were analyzed for metal content by atomic absorption spectrophotometry (908 AA, GBC), with background correction. All samples were put to a final volume of $100 \mathrm{ml}$. To ensure a satisfactory accuracy of the analysis, Standard Reference Material of National Institute and Technology and internal reference materials were used for precision, quality assurance, and control for selected metal measurements. All the material used was previously washed with $\mathrm{HNO}_{3}$ ultra-pure (J.T. Baker) for $14224 \mathrm{hrs}$. For each measurement, the average values of three replicates were recorded. Metal content is reported as $\mathrm{mg} / \mathrm{L}$. ( $\mathrm{Zn}, \mathrm{Cd}, \mathrm{Pb}, \mathrm{Cu}, \mathrm{Mn}, \mathrm{Cr}$ ). 144 Detection limits of the atomic absorption spectrophotometer are: $0.0005 \mathrm{mg} / \mathrm{L}$ for $\mathrm{Zn}, 0.01 \mathrm{mg} / \mathrm{L}$ for $\mathrm{Pb}, 0.0015 \mathrm{mg} / \mathrm{L}$ for $\mathrm{Mn}, 0.003 \mathrm{mg} / \mathrm{L}$ for $\mathrm{Cr}, 0.001 \mathrm{mg} / \mathrm{L}$ for $\mathrm{Cu}, 0.0004 \mathrm{mg} / \mathrm{L}$ for $\mathrm{Cd}$ and $0.005 \mathrm{mg} / \mathrm{L}$ for $\mathrm{Fe}$. 


\subsection{DNA extraction and Sequencing}

DNA was extracted from water samples using a DNeasy PowerWater Kit

150 (QIAGEN, Hilden, Germany). For each sample, an Illumina library was prepared from total DNA using the TruSeq kit v2 (Illumina, Inc., San Diego, CA, USA) 152 following the manufacturer's specifications with an average fragment size of 500 bp. The sequencing was performed on the NextSeq500 (Illumina, Inc., San

154 Diego, CA, USA) platform with a 150-cycle configuration, generating paired-end reads with a length of $75 \mathrm{bp}$.

\subsection{Data Analysis}

After performing a quality control analysis using the FASTQC program and lowquality sequences were removed using an in-house Perl script (Andrews, 2010), the taxonomic profiling was performed using the raw reads with the software MetaPhlan v2.0 (Truong et al., 2017) using the following parameters: --bt2_ps sensitive-local --min_alignment_len 95 --input_typefastq. For the metagenome assembly, gene prediction and annotation, the raw reads were assembled using Megahit v1.1.3, Metagenemark v3.36, and Trinotate v3.1.1, respectively. The parameters used for Megahit were: --k-min 25 --k-max 75 --k-step 10 -m 0.4 -no-mercy. The parameters used in Metagenemark were: -a - $d$ - $f$ G $-m$ MetaGeneMark_v1.mod. For Trinotate, default parameters were used. GhostKOALA was used for KEGG's annotation and $\mathrm{K}$ number assignment of metagenomic sequences (Kanehisha et al., 2016).

\subsection{Biodegradative activities prediction by hidden markov models ( $\mathrm{hmm}$ ) profiles}

HMMER was used for searching sequence homologs related to PET and polystyrene biodegradation. Furthermore, sequences involved in metals 
172 attenuation were mined as well in Apatlaco River metagenomes (da Fonseca et al., 2016). Were selected the most representative sequences belonging to:(i) 11

174 few well-characterized PET hydrolases (Danso et al., 2018), (ii) two sequences of styrene monooxygenase (StyA) functionally characterized and (iii) for metals 176 were selected the well know transporters of $\mathrm{Cd}$ and $\mathrm{Pb}$. After, for the construction of multiple independent alignments, we use Muscle (Edgar, 2009).

178 The alignments were manually cured, and hmm profiles were generated with the hmm build command. Subsequently, were search with these models into the metagenomes obtained from Apatlaco River S1, S2, S3, S4 containing 499,126 sequences. We selected significant query matches with E-vale minimum of

1820.001 . Finally, hits with better E-values in each metagenome were selected for Blast search against the non-redundant NCBI database to assign potential taxonomies.

\section{Results and Discussion}

2.1 Functional potential of the microbial community related to bioremediation in the Apatlaco River

The Apatlaco River is characterized by the presence of a broad spectrum of microorganisms with the metabolic potential to carry out bioremediation activities (Breton-Deval et al. 2019). The genera presented in table 2 are

192 microorganisms located along the river that have been tested experimentally in previous research for their ability to tolerate or degrade pollutants (Gallego et al., 2006; Hovasse et al., 2016; Mattes et al., 2008; Mekuto et al., 2018).

In S1 the genera with these abilities were Thiomonas, Polaromonas, Pedobacter, and Myroides, the first three genera are specialists in heavy metal 
accumulation, biosorption, and reduction and the last one inorganic material mineralization (Magic-Knezev et al., 2009; Margesin and Zhang, 2013; Mekuto et al., 2018; Zheng et al., 2014). The Polaromonas genus found in S1 is representative of clean water with low levels of COD and nitrogen, just like S1 is (Table 1). The other genera perhaps are present due to the selective pressure 202 of the high level of $\mathrm{Pb}$ and $\mathrm{Cu}$. S2 exhibits genera including Pedobacter, Myroides, Pseudomonas and Acinetobacter; of which the last two have the metabolic machinery to degrade different compounds such as detergents, dyes, pesticides, hydrocarbons, clothianidin and cyprodinil (Ganguli and Tripathi, 2002; Paisio et al., 2016; Wang et al., 2019). In S2, all physicochemical parameters increased and DO decrease as a consequence of the rise of COD, the entire ecosystem has changed, and the microbial communities have been drastically modified. At this point of the river, the most abundant microorganism is Acinetobacter whose presence may be a result of waste discharge and growth prompted by the physicochemical conditions of the stream. Genera from

212 the two previous sample points, including Thiomonas, Myroides, Pseudomonas, Acinetobacter and Aeromonas, are also present at S3. This point shows an increase in almost all levels of physicochemical parameters, except in $\mathrm{Pb}$ and OD. Finally, S4 includes Thiomonas, Myroides and Pseudomonas genera 216 similar to earlier points in the river. However, Thauera genera are unique to this part of the river and have the potential to tolerate many metals including $\mathrm{Zn}, \mathrm{Cd}$, $218 \mathrm{Co}, \mathrm{Cu}, \mathrm{Ni}, \mathrm{Pb}, \mathrm{Cr}, \mathrm{Hg}$ and $\mathrm{Se}$ (Fang et al., 2018). S4 is the last point before the river ends and the physicochemical conditions are very similar to the second sample point (S2) except for the higher levels of TKN and TDS due to the 
accumulation of nitrates, phosphorus, sodium, magnesium, and metals discharged along the length of the river.

\subsection{Energy flux and the bioremediation potential}

Microbial transformations of contaminants take place as a consequence of the

use of pollutants as a source of carbon or as an electron acceptor (Fig. 2).

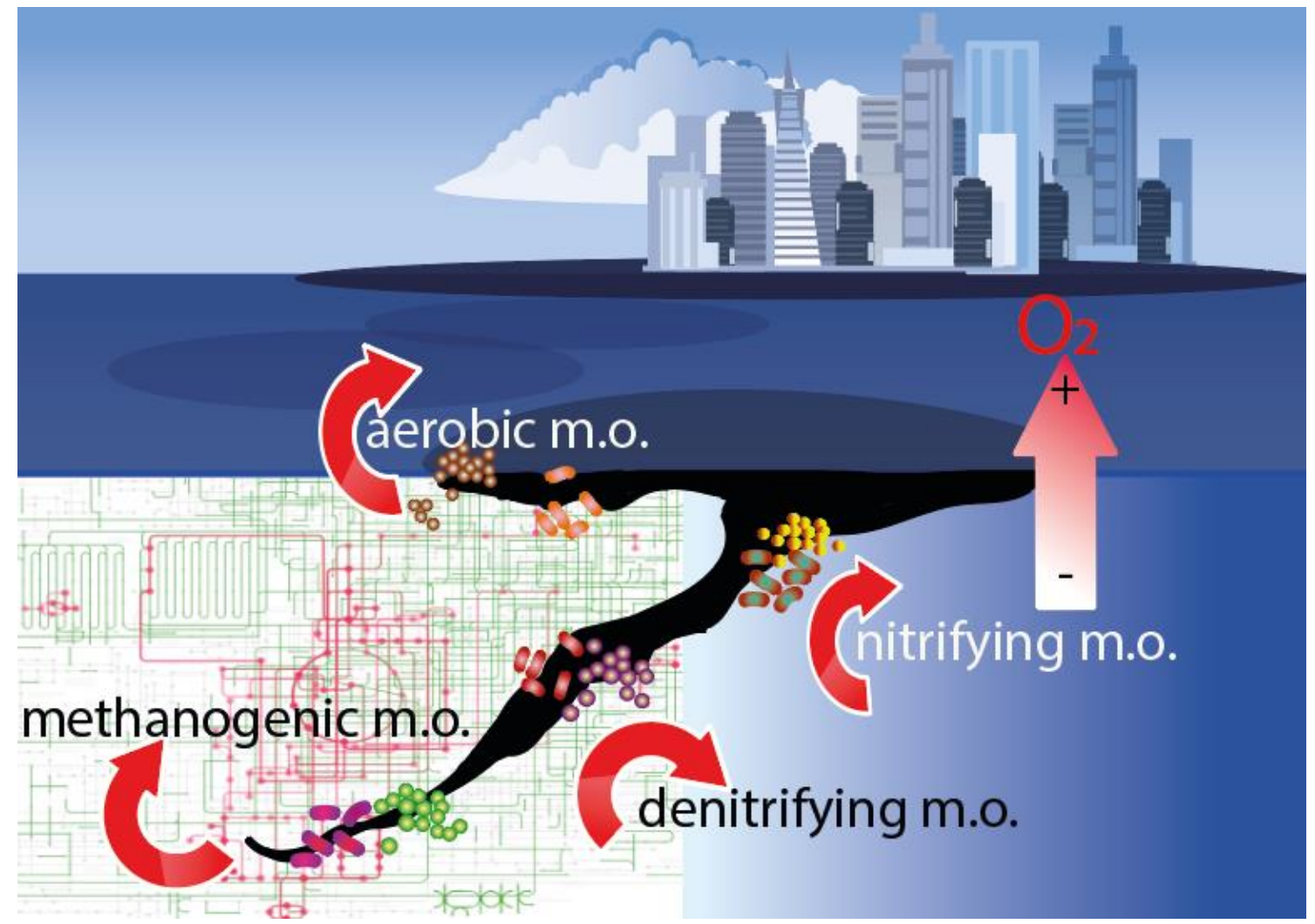

Figure 2 The dynamic microbial transformations of contaminants take place as a consequence of the use of pollutants as a source of carbon or as an electron acceptor

$\mathrm{O}_{2}$ acts as the terminal electron acceptor in the process of aerobic respiration

while $\mathrm{NO}_{3}, \mathrm{CO}_{2}$ or fumarate can be used as terminal electron acceptors for anaerobic respiration. Aerobic respiration is energetically more efficient than other electron acceptors. However, $\mathrm{O}_{2}$ is not always the most available electron acceptor at all parts of the rivers. Despite this, the results showed evidence of microorganisms, which can use another electron acceptor such as nitrate. 
Regarding the aerobic degradation of pollutants predicted by the KEGG ortholog groups (KOs), there are several enzymes involved in the biodegradation of aromatic compounds. The enzymes found at S1 were 240 dioxygenase and dehydrogenase, which can degrade Catechol, Biphenyl, Naphthalene, and Phthalate. While S2 and S3 are both rich in dioxygenase and 242 decarboxylating dehydrogenases involved in the degradation of Toluene, Fluorobenzoate, Xylene, Phenylpropanoate, and Phenol. S3 also has 244 monooxygenases which degrade Benzene. All of the earlier mentioned enzymes were also found at S4. These compounds are used to make 246 lubricants, drugs, dyes, pesticides, and rubbers. Given that an industrial park is located close to the river, the afore mentioned presence of enzymes suggests 248 that the industrial park does not have the necessary water plant to correctly treat their effluents and perhaps this constant discharge have selected the 250 microbial community.

When $\mathrm{O}_{2}$ is scarce, nitrate is the next most energetically favorable electron 252 acceptor which can reduce or denitrify bacteria; this last group is facultative anaerobes. The river is a dynamic system where several processes happen at 254 the same time, some groups of bacteria use $\mathrm{O}_{2}$ while in oxygen deficient areas the nitrate reducing, or denitrifying bacteria use nitrogen. Figure 3 shows the 256 logarithmic rise in the enzyme levels related to the increased level of TN. The enzymes involved in the nitrogen cycle were mainly oxidoreductases. Under the assumption of a different selective pressure gradient along the river, due to steady pollutant discharges, among S1-S4 sites we observe a differential distribution of the molecular functions assigned to various metabolic processes related to energy metabolism (Oxidative phosphorylation, Nitrogen metabolism, 
262 Methane metabolism; (Anexo A). Which suggests functional specialization in the communities that inhabit each point, and could determine the partition in a metabolic niche among different Apatlaco's River prokaryotic communities that help to contend with anthropogenic contamination. These ultimate is maybe 266 favorable in environments with dynamics resource availability.

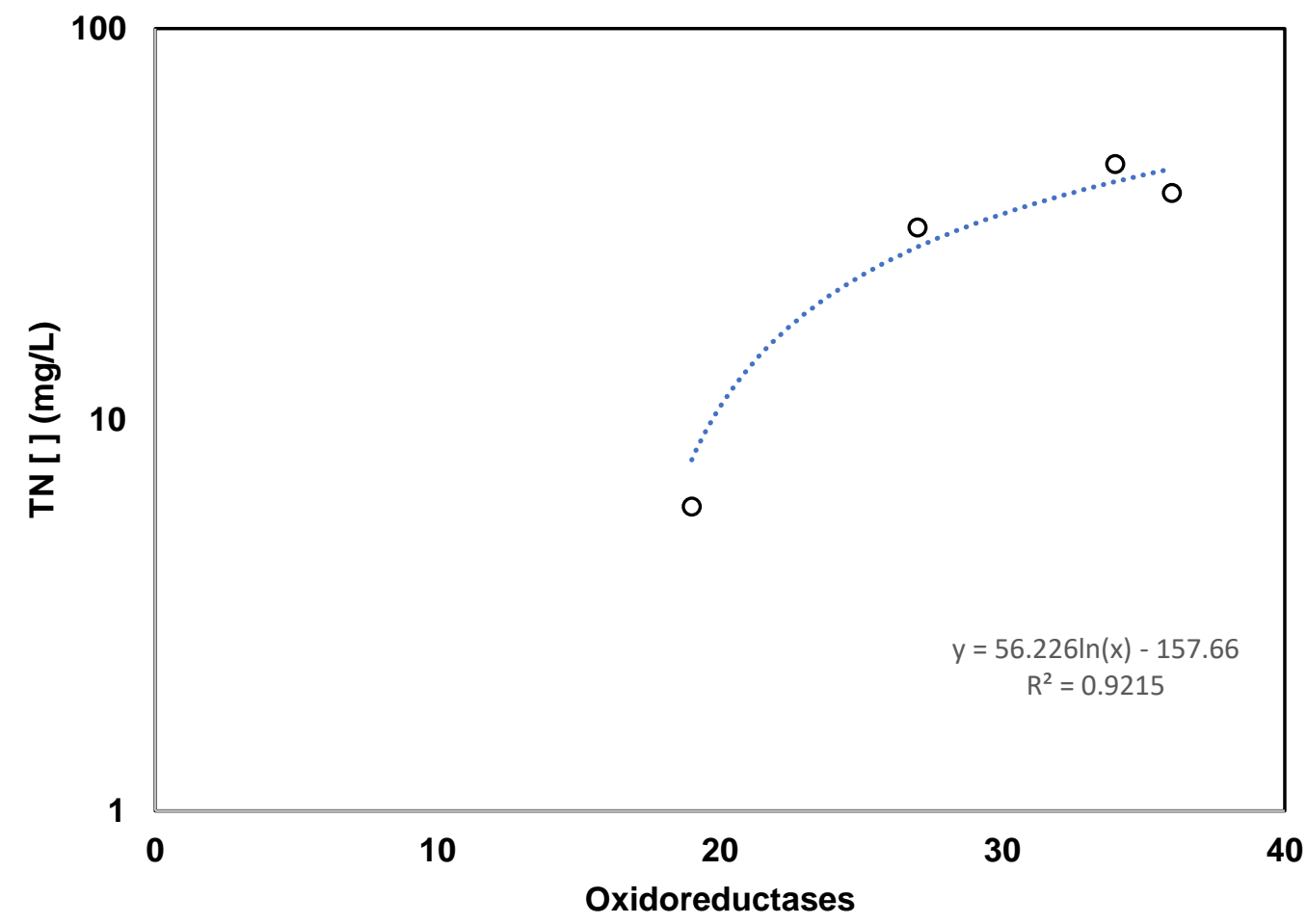

268 Figure 3 Logarithmic rise in the enzyme levels related to the increased level of Total nitrogen (TN).

270

Concerning the methanogenic pathway, the drivers are methanogens which

272 produce methane as a byproduct and methanotrophs that consume that methane (Angelidaki W., 2004). The four sample sites have similar enzymes at particular points of the pathway such as the trimethylamine- $\mathrm{N}$-oxide reductase (KO7811), a useful transmembrane electron carrier. However, there are specific enzymes at every point. S1 and S4 have genes for the hetero disulfide reductase $(\mathrm{Hdr})$ required for the final reactions of the methane pathway. S1 also 
278 indicated the presence of methane monooxygenase (K16157), which is very useful for the degradation of alkanes, alkenes, ammonia, and aromatic compounds. At the same time, S2 has methanol dehydrogenases (K14028) to degrade ethanol, chloroethanol, and formaldehyde and S3 has a pyruvate 282 ferredoxin oxidoreductase (K00169) useful for the degradation of nitrotoluene. This enzyme has been reported in Methano bacterium thermo autotrophicum, and in Halobacterium halobium, neither microorganism are not currently in that point however this enzyme is a homologous to a pyruvate ferredoxin

oxidoreductase from Thauera sp. (Dörner and Boll, 2002) S4 has a methyl coenzyme M reductase (K00399) able to transfer sulfur groups. Concerning 288 methanotrophs, all of the points showed trimethylamine- $\mathrm{N}$-oxidoreductase (K07811-K07812) indicative of methane oxidation by methanotrophs.

2.3 Microbial genes and enzymes involved in the degradation of industrial 292 pollutants: plastics and metals

The Apatlaco River is a basin mostly polluted with solid plastic residues such as 294 PET derivatives and polystyrene foams among others. Every year the basin receives on average 5 tons of plastics (SEMARNAT, 2008) that remain without significant biological alteration. Although some databases include information about xenobiotic degradation pathways and the genes and enzymes involved in 298 their degradation, some pollutants, such as PET and polystyrene, are missing. In order to find enzymes involved in PET and polystyrene degradation, Hidden

Markov Model strategies were applied to search for potential homologous biodegradative sequences in several metagenomes obtained from The Apatlaco 302 River (Anexo B). As expected, the PET hydrolase candidate's genes belong to 
the superfamily of alpha/beta-hydrolases (pfamPF00561). Almost $50 \%$ of the sequences belong to the Flavobacteriia class. Interestingly, two sequences contain proteolytic domains suggesting similarities with the catalytic mechanisms of several peptidases. Eleven sequences appear to be classic esterase-lipase proteins, related to ester hydrolysis in a broad xenobiotic substrate family. Danso et al., 2018, retrieved two metagenomic PET hydrolase sequences from $\mathrm{hmm}$ probabilistic models that were functionally active in polycaprolactone and PET hydrolysis, supporting this approaching to undermine the metabolic potential in environmental microbiomes to degrade priority 312 pollutants. Several studies suggest that the degradation of polystyrene by bacteria occurs by oxidizing individual units of styrene, through monooxygenase activities (Ho et al., 2018). We found six oxygenase (StyA) candidate's genes (Anexo B). Homologous sequences in Pseudomonas and Rhodococcusopacus (Otto et al., 2004; Tischler et al., 2010) are responsible for activation in aerobic bacterial styrene degradation. We hypothesized that these metagenomic

318 sequences could support the Apatlaco River's microbial communities in the biodegrading of PET and polystyrene.

320 Other compounds that are missing in most databases include heavy metals, and this is because some metals such as $\mathrm{Cu}, \mathrm{Zn}$, and Fe are protein cofactors 322 while other metals such as $\mathrm{Cd}, \mathrm{Ag}$ and $\mathrm{Pb}$ do not play a role in bacterial metabolism (L. Wood et al., 2016). However, even at deficient concentrations, not essential metals or essential metals at high levels are toxic for microorganisms and it can be difficult to distinguish between the pathways involved in metabolism and the different strategies that microorganisms employ to deal with metals. Microorganisms can adsorb metals, change their speciation 
328 to less harmful compounds, and mineralize (Sharma and Pant, 2018). Biosorption is mostly carried out by proteins called metallothioneins while speciation is a common reduction mechanism; some examples are $\mathrm{Cr}^{6+}$ to $\mathrm{Cr}^{3+}$, $\mathrm{AsO}_{4}^{3-}$ to $\mathrm{AsO}_{3}^{3-}, \mathrm{Hg}^{2+}$ to $\mathrm{Hg}^{0}$ (Gutiérrez et al., 2018a).

332 The Aplataco's water has some metals; however, only $\mathrm{Pb}$ and $\mathrm{Cd}$ levels were above the national standards (Table 1 ). $\mathrm{Cd}$ and $\mathrm{Pb}$ are metals that do not have any biological function and are very toxic because they may affect the renal, hematologic, and nervous systems. However, some reports of bacteria can tolerate $1350 \mathrm{mg} / \mathrm{L}$ of $\mathrm{Cd}$ and $1900 \mathrm{mg} / \mathrm{L}$ of $\mathrm{Pb}$ (Marzan et al., 2017). The genes involved in Cd resistance are RND exporters composed of the following 338 proteins $\mathrm{CzcA}, \mathrm{CzcB}, \mathrm{CzcZ}, \mathrm{CzcN}, \mathrm{CzcD}, \mathrm{CzcR}, \mathrm{CzcS}$ which form transport systems that are able to export ions such as $\mathrm{Zn} 2+, \mathrm{Co} 2+$, and $\mathrm{Cd} 2+$ across the membranes. The application of Hidden Markov Model to find homologous sequences of these proteins allowed us the association with some 342 microorganisms present in the river, with the ability to tolerate $\mathrm{Cd}$ (Anexo C). The number of species identified at each sample site is around five, except for S3 where $11 \mathrm{Cd}$ tolerant species were found with a particular abundance of Flavobacterium. This same point has the highest level of $\mathrm{Cd}$ of the whole river $(0.19 \mathrm{mg} / \mathrm{L})$. It is possible that the elevated level of $\mathrm{Cd}$ stimulates a more significant presence of the microorganism. In the case of $\mathrm{Pb}$, the genes involved in $\mathrm{Pb}$ resistance are metal-transporting ATPase for $\mathrm{Cd}$, the ATPase for $\mathrm{Cu}+$ CopA, the ATPase ZntA and the metallothionein protein smtA (Gutiérrez et al., 2018a). SmtA has been reported in Synechococcus, Pseudomonas, and Yersinia pestis (Gutiérrez et al., 2018b). While CopA and ZntA have been described in E. coli and Enterococcus hirae (Argudín et al., 2019). Our results 
identified microorganisms that haven't been previously reported, such as

Limnohabitans, Cellvibrio, Polynucleobacter, or Azoarcus, which can tolerate Pb (Anexo D).

\section{Conclusion}

358 Our result allowed us to identify the microorganisms present along the Apatlaco River with the metabolic potential to carry out bioremediation activities of the 360 following genera Thiomonas, Polaromonas, Pedobacter, Myroides, Pseudomonas, Acinetobacter, Aeromonas and Thauera. Furthermore, enzymes 362 involved in the degradation of several priority pollutants were identified. The site $\mathrm{S} 1$ is rich in dioxygenase and dehydrogenase which can degrade Catechol, 364 Biphenyl, Naphthalene and Phthalate. While, S2 and S3 are rich in dioxygenase and decarboxylating dehydrogenases to degrade Toluene, Fluorobenzoate, 366 Xylene, Phenylpropanoate, and Phenol. S3 also has monooxygenases which degrade Benzene. All of the earlier mentioned enzymes were also found at S4. Although an oligotrophic stage prevails in the studied microbial communities of the Apatlaco's River, the four points analyzed seem to show some specialization concerning energy metabolism, as well as the potential to obtain new biocatalysts for biodegradation of emerging pollutants such as plastic wastes. Finally, the bioinformatic analysis allowed us to identify microorganisms that haven't been previously reported as a $\mathrm{Pb}$ tolerant (Limnohabitans, 374 Cellvibrio, Polynucleobacter, or Azoarcus) for further research. 


\section{Acknowledgments}

378 The authors thank Instituto de Biotecnologia, UNAM for financial support to this research (P-9850). Also, LB-D thank to Consejo Nacional de Ciencia y

380 Tecnología (CONACYT) and their program CATEDRAS for support the Project 285. We also like to thank the Unidad Universitaria de Secuenciación Masiva y

382 Bioinformática (UUSMB) of the Instituto de Biotecnología, UNAM, for advice on DNA sequencing and Maria A. Millan for their help with the supplementary data.

384 The map used in this paper was made by Karina E Rios-Ramos with data shared by the LISIG of the CIByC-UAEM.

\section{References}

388

390

392

394

396

398

400

402

404

406

408

410

412

414

416

418

Andrews, 2010. FastQC: a quality control tool for high throughput sequence data.

Angelidaki W., I. and S., 2004. Assesment of the anaerobic biodegradabilty of macropollutants. Reviews in environmental science and bio/technology 3,

Argudín, M.A., Hoefer, A., Butaye, P., 2019. Heavy metal resistance in bacteria from animals. Research in Veterinary Science 122, 132-147. doi:10.1016/j.rvsc.2018.11.007

Arora, P.K., Bae, H., 2014. Integration of bioinformatics to biodegradation. Biological Procedures Online 16, 1-10. doi:10.1186/1480-9222-16-8

Breton-Deval, Luz ; Juarez, Katy; Sanchez-Flores, Alejandro; Vera-Estrella, R., 2019. Water quality assessments and metagenomic analysis of the polluted river Apatlaco, Mexico. BioRxiv 1-25.

Chen, B.Y., Hung, J.Y., Shiau, T.J., Wei, Y.H., 2013. Exploring two-stage fermentation strategy of polyhydroxyalkanoate production using Aeromonas hydrophila. Biochemical Engineering Journal 78, 80-84. doi:10.1016/j.bej.2013.04.024

Chen, X., He, S., Liu, X., Hu, J., 2018. Biobegradation and metabolic mechanism of cyprodinil by strain Acinetobacter sp. from a contaminatedagricultural soil in China. Ecotoxicology and Environmental Safety 159, 190-197. doi:10.1016/j.ecoenv.2018.04.047

Chen, Z., Wang, Y., Xia, D., Jiang, X., Fu, D., Shen, L., Wang, H., Li, Q.B., 2016. Enhanced bioreduction of iron and arsenic in sediment by biochar amendment influencing microbial community composition and dissolved organic matter content and composition. Journal of Hazardous Materials 311, 20-29. doi:10.1016/j.jhazmat.2016.02.069

da Fonseca, R.R., Albrechtsen, A., Themudo, G.E., Ramos-Madrigal, J., Sibbesen, J.A., Maretty, L., Zepeda-Mendoza, M.L., Campos, P.F., Heller, R., Pereira, R.J., 2016. Next-generation biology: Sequencing and data analysis approaches for non-model organisms. Marine Genomics 30, 3-13. doi:10.1016/j.margen.2016.04.012

Dörner, E., Boll, M., 2002. Properties of 2-oxoglutarate:Ferredoxin 
oxidoreductase from Thauera aromatica and its role in enzymatic reduction of the aromatic ring. Journal of Bacteriology 184, 3975-3983.

doi:10.1128/JB.184.14.3975-3983.2002

422

424

426

428

430

432

434

436

438

440

442

444

446

448

450

452

454

456

458

460

462

Du, L.N., Li, G., Zhao, Y.H., Xu, H.K., Wang, Y., Zhou, Y., Wang, L., 2015.

Efficient metabolism of the azo dye methyl orange by Aeromonas sp. strain DH-6: Characteristics and partial mechanism. International Biodeterioration and Biodegradation 105, 66-72. doi:10.1016/j.ibiod.2015.08.019

Duy Tin Truong, Adrian Tett, Edoardo Pasolli, Curtis Huttenhower, N.S., 2017. Microbial strain-level population structure and genetic diversity from metagenomes. Genome Research 27, 626-638.

Dvořák, P., Nikel, P.I., Damborský, J., de Lorenzo, V., 2017. Bioremediation 3.0: Engineering pollutant-removing bacteria in the times of systemic biology. Biotechnology Advances 35, 845-866. doi:10.1016/j.biotechadv.2017.08.001

Fang, H., Zhang, H., Han, L., Mei, J., Ge, Q., Long, Z., Yu, Y., 2018. Exploring bacterial communities and biodegradation genes in activated sludge from pesticide wastewater treatment plants via metagenomic analysis. Environmental Pollution 243, 1206-1216. doi:10.1016/j.envpol.2018.09.080

Fernández, P.M., Viñarta, S.C., Bernal, A.R., Cruz, E.L., Figueroa, L.I.C., 2018. Bioremediation strategies for chromium removal: Current research, scaleup approach and future perspectives. Chemosphere. doi:10.1016/j.chemosphere.2018.05.166

Gallego, V., García, M.T., Ventosa, A., 2006. Pedobacter aquatilis sp. nov., isolated from drinking water, and emended description of the genus Pedobacter. International Journal of Systematic and Evolutionary Microbiology 56, 1853-1858. doi:10.1099/ijs.0.64176-0

Ganguli, A., Tripathi, A.K., 2002. Bioremediation of toxic chromium from electroplating effluent by chromate-reducing Pseudomonas aeruginosa A2Chr in two bioreactors. Applied Microbiology and Biotechnology 58, 416420. doi:10.1007/s00253-001-0871-x

Ghosh, A., Bhadury, P., 2018. Methods of Assessment of Microbial Diversity in Natural Environments, Microbial Diversity in the Genomic Era. Elsevier Inc. doi:10.1016/b978-0-12-814849-5.00001-0

González-Toril, E., Aguilera, Á., 2018. Microbial Ecology in Extreme Acidic Environments. Microbial Diversity in the Genomic Era 227-238. doi:10.1016/b978-0-12-814849-5.00014-9

Gutiérrez, J.-C., de Francisco, P., Amaro, F., Díaz, S., Martín-González, A., 2018a. Structural and Functional Diversity of Microbial Metallothionein Genes. Microbial Diversity in the Genomic Era 387-407. doi:10.1016/b9780-12-814849-5.00022-8

Gutiérrez, J.-C., de Francisco, P., Amaro, F., Díaz, S., Martín-González, A., 2018b. Structural and Functional Diversity of Microbial Metallothionein Genes. Microbial Diversity in the Genomic Era 387-407. doi:10.1016/b9780-12-814849-5.00022-8 
Hovasse, A., Bruneel, O., Casiot, C., Desoeuvre, A., Farasin, J., Hery, M., Van

466 Dorsselaer, A., Carapito, C., Arsène-Ploetze, F., 2016. Spatio-Temporal Detection of the Thiomonas Population and the Thiomonas Arsenite Oxidase Involved in Natural Arsenite Attenuation Processes in the Carnoulès Acid Mine Drainage. Frontiers in Cell and Developmental Biology 4, 1-14. doi:10.3389/fcell.2016.00003

IMTA, 2008. Evaluacion Ambiental Recuperaciòn Ambiental de la Cuenca del Rìo Apatlaco.

Kumar, S.S., Shantkriti, S., Muruganandham, T., Murugesh, E., Rane, N., Govindwar, S.P., 2016. Bioinformatics aided microbial approach for bioremediation of wastewater containing textile dyes. Ecological Informatics 31, 112-121. doi:10.1016/j.ecoinf.2015.12.001

L. Wood, J., Liu, W., Tang, C., E. Franks, A., 2016. Microorganisms in heavy metal bioremediation: strategies for applying microbial-community engineering to remediate soils. AIMS Bioengineering 3, 211-229. doi:10.3934/bioeng.2016.2.211

Li, R., Liu, S., Zhang, G., Ren, J., Zhang, J., 2013. Biogeochemistry of nutrients in an estuary affected by human activities: The Wanquan River estuary, eastern Hainan Island, China. Continental Shelf Research 57, 18-31. doi:10.1016/j.csr.2012.02.013

Liu, J., Chen, X., Shu, H. yue, Lin, X. rui, Zhou, Q. xing, Bramryd, T., Shu, W. sheng, Huang, L. nan, 2018. Microbial community structure and function in sediments from e-waste contaminated rivers at Guiyu area of China. Environmental Pollution 235, 171-179. doi:10.1016/j.envpol.2017.12.008

Magic-Knezev, A., Wullings, B., Van Der Kooij, D., 2009. Polaromonas and Hydrogenophaga species are the predominant bacteria cultured from granular activated carbon filters in water treatment. Journal of Applied Microbiology 107, 1457-1467. doi:10.1111/j.1365-2672.2009.04337.x

Margesin, R., Zhang, D.C., 2013. Pedobacter ruber sp. nov., a psychrophilic bacterium isolated from soil. International Journal of Systematic and Evolutionary Microbiology 63, 339-344. doi:10.1099/ijs.0.039107-0

Marzan, L.W., Hossain, M., Mina, S.A., Akter, Y., Chowdhury, A.M.M.A., 2017. Isolation and biochemical characterization of heavy-metal resistant bacteria from tannery effluent in Chittagong city, Bangladesh: Bioremediation viewpoint. Egyptian Journal of Aquatic Research 43, 65-74. doi:10.1016/j.ejar.2016.11.002

Mattes, T.E., Alexander, A.K., Richardson, P.M., Munk, A.C., Han, C.S., Stothard, P., Coleman, N. V., 2008. The genome of Polaromonas sp. strain JS666: Insights into the evolution of a hydrocarbon- and xenobioticdegrading bacterium, and features of relevance to biotechnology. Applied and Environmental Microbiology 74, 6405-6416. doi:10.1128/AEM.0019708

Megharaj, M., Ramakrishnan, B., Venkateswarlu, K., Sethunathan, N., Naidu, R., 2011. Bioremediation approaches for organic pollutants: A critical 
perspective. Environment International 37, 1362-1375.

doi:10.1016/j.envint.2011.06.003

Mekuto, L., Ntwampe, S.K.O., Mudumbi, J.B.N., 2018. Microbial communities associated with the co-metabolism of free cyanide and thiocyanate under alkaline conditions. 3 Biotech 8. doi:10.1007/s13205-018-1124-3

Mekuto, L., Ntwampe, S.K.O., Mudumbi, J.B.N., Akinpelu, E.A., MewaNgongang, M., 2017. Metagenomic data of free cyanide and thiocyanate degrading bacterial communities. Data in Brief. doi:10.1016/j.dib.2017.06.049

Moeller-Chávez, G., Seguí-Amórtequi, L., Alfranca-Burriel, O., EscalanteEstrada, V., Pozo-Román, F., Rivas-Hernández, A., 2004. Water reuse in the Apatlaco River Basin (Mexico): A feasibility study. Water Science and Technology 50, 329-337.

Naz, T., Khan, M.D., Ahmed, I., Rehman, S.U., Rha, E.S., Malook, I., Jamil, M., 2016. Biosorption of heavy metals by Pseudomonas species isolated from sugar industry. Toxicology and Industrial Health 32, 1619-1627. doi:10.1177/0748233715569900

Osborne, T.H., Jamieson, H.E., Hudson-Edwards, K.A., Nordstrom, D.K., Walker, S.R., Ward, S.A., Santini, J.M., 2010. Microbial oxidation of arsenite in a subarctic environment: Diversity of arsenite oxidase genes and identification of a psychrotolerant arsenite oxidiser. BMC Microbiology 10. doi:10.1186/1471-2180-10-205

Paisio, C.E., Talano, M.A., González, P.S., Magallanes-Noguera, C., KurinaSanz, M., Agostini, E., 2016. Biotechnological tools to improve bioremediation of phenol by Acinetobacter sp. RTE1.4. Environmental Technology (United Kingdom) 37, 2379-2390. doi:10.1080/09593330.2016.1150352

Peters, M., Guo, Q., Strauss, H., Wei, R., Li, S., Yue, F., 2019. Contamination patterns in river water from rural Beijing: A hydrochemical and multiple stable isotope study. Science of the Total Environment 654, 226-236. doi:10.1016/j.scitotenv.2018.10.423

Ramadass, K., Megharaj, M., Venkateswarlu, K., Naidu, R., 2018. Bioavailability of weathered hydrocarbons in engine oil-contaminated soil: Impact of bioaugmentation mediated by Pseudomonas spp. on bioremediation. Science of the Total Environment 636, 968-974. doi:10.1016/j.scitotenv.2018.04.379

Roy, U., Sengupta, S., Banerjee, P., Das, P., Bhowal, A., Datta, S., 2018. Assessment on the decolourization of textile dye (Reactive Yellow) using Pseudomonas sp. immobilized on fly ash: Response surface methodology optimization and toxicity evaluation. Journal of Environmental Management 223, 185-195. doi:10.1016/j.jenvman.2018.06.026

Samal, K., Dash, R.R., Bhunia, P., 2017. Treatment of wastewater by vermifiltration integrated with macrophyte filter: A review. Journal of Environmental Chemical Engineering 5, 2274-2289. 
doi:10.1016/j.jece.2017.04.026

552

554

556

558

560

562

564

566

568

570

572

574

576

578

580

582

584

586

588

590

592

SEMARNAT, 2008. La cuenca del río Apatlaco.

Sharma, V., Pant, D., 2018. Structural basis for expanding the application of bioligand in metal bioremediation: A review. Bioresource Technology 252, 188-197. doi:10.1016/j.biortech.2017.12.070

Singh, R., Paul, D., Jain, R.K., 2006. Biofilms: implications in bioremediation. Trends in Microbiology 14, 389-397. doi:10.1016/j.tim.2006.07.001

Suthersan, S.S., 1999. In situ bioremediation. Remediation engineering: desing concepts 123-158. doi:978-1-56670-137-2

Techtmann, S.M., Hazen, C., 2016. Metagenomic applications in environmental monitoring and bioremediation. Journal of Industrial Microbiology \& Biotechnology. doi:10.1007/s10295-016-1809-8

Uhrynowski, W., Debiec, K., Sklodowska, A., Drewniak, L., 2017. The role of dissimilatory arsenate reducing bacteria in the biogeochemical cycle of arsenic based on the physiological and functional analysis of Aeromonas sp. O23A. Science of the Total Environment 598, 680-689. doi:10.1016/j.scitotenv.2017.04.137

Wang, X., Xue, L., Chang, S., He, X., Fan, T., Wu, J., Niu, J., Emaneghemi, B., 2019. Bioremediation and metabolism of clothianidin by mixed bacterial consortia enriched from contaminated soils in Chinese greenhouse. Process Biochemistry. doi:10.1016/j.procbio.2018.12.031

Wang, Z., Su, Y., Zhang, Y., Guo, H., Meng, D., Wang, Y., 2016. Ecology-types determine physicochemical properties and microbial communities of sediments obtained along the Songhua River. Biochemical Systematics and Ecology 66, 312-318. doi:10.1016/j.bse.2016.04.008

Wasi, S., Tabrez, S., Ahmad, M., 2013. Use of Pseudomonas spp. for the bioremediation of environmental pollutants: A review. Environmental Monitoring and Assessment 185, 8147-8155. doi:10.1007/s10661-0133163-x

Yagi, J.M., Sims, D., Brettin, T., Bruce, D., Madsen, E.L., 2009. The genome of Polaromonas naphthalenivorans strain CJ2, isolated from coal tarcontaminated sediment, reveals physiological and metabolic versatility and evolution through extensive horizontal gene transfer. Environmental Microbiology 11, 2253-2270. doi:10.1111/j.1462-2920.2009.01947.x

Zhang, S., Gedalanga, P.B., Mahendra, S., 2017. Advances in bioremediation of 1,4-dioxane-contaminated waters. Journal of Environmental Management 204, 765-774. doi:10.1016/j.jenvman.2017.05.033

Zhang, Y., Tang, Y., Qin, Z., Luo, P., Ma, Z., Tan, M., Kang, H., Huang, Z., 2019. A novel manganese oxidizing bacterium-Aeromonas hydrophila strain DS02: $\mathrm{Mn}$ (II) oxidization and biogenic $\mathrm{Mn}$ oxides generation. Journal of Hazardous Materials 367, 539-545. doi:10.1016/j.jhazmat.2019.01.012

Zhao, Y., Bai, Y., Guo, Q., Li, Z., Qi, M., Ma, X., Wang, H., Kong, D., Wang, A., Liang, B., 2019. Bioremediation of contaminated urban river sediment with 
$594 \quad$ methanol stimulation: Metabolic processes accompanied with microbial community changes. Science of the Total Environment 653, 649-657.

596 doi:10.1016/j.scitotenv.2018.10.396

Zhao, Y.W., Zhou, L.Q., Dong, B.Q., Dai, C., 2019. Health assessment for urban rivers based on the pressure, state and response framework-A case study of the Shiwuli River. Ecological Indicators 99, 324-331. doi:10.1016/j.ecolind.2018.12.023

Zheng, Y., Xiao, Y., Yang, Z.H., Wu, S., Xu, H.J., Liang, F.Y., Zhao, F., 2014. The bacterial communities of bioelectrochemical systems associated with the sulfate removal under different pHs. Process Biochemistry. 
Table 2 Microorganism with bioremediation potential

\begin{tabular}{|c|c|c|c|c|c|}
\hline Microorganism & Location & Biologicalactivity & Compounds & Pathogen & Ref. \\
\hline Thiomonas sp. & $\begin{array}{l}\text { S1, S3, } \\
\text { S4 }\end{array}$ & $\begin{array}{l}\text { Biofilms - } \\
\text { Reduction }\end{array}$ & As, $\mathrm{S}$, & No & $\begin{array}{c}\text { (Zheng et al., } \\
\text { 2014), 6-8 }\end{array}$ \\
\hline $\begin{array}{c}\text { Polaromonas } \\
\text { sp. }\end{array}$ & S1 & Oxidation, biofilms & Hg, As,alkanes, Pyrene & No & $\begin{array}{l}\text { (Mattes et } \\
\text { al., 2008; } \\
\text { Osborne et } \\
\text { al., 2010; } \\
\text { Singh et al., } \\
\text { 2006; Yagi et } \\
\text { al., 2009) }\end{array}$ \\
\hline Pedobacter sp. & $\mathrm{S} 1, \mathrm{~S} 2$ & $\begin{array}{c}\text { Reduction } \\
\text { desasimilative }\end{array}$ & $\mathrm{As}(\mathrm{V})$ & opportunistic & $\begin{array}{c}\text { (Chen et al., } \\
\text { 2016) }\end{array}$ \\
\hline Myroides sp. & $\begin{array}{l}\text { S1, S2, } \\
\text { S3, S4 }\end{array}$ & & $\begin{array}{c}\mathrm{CN}^{-}, \underset{\text { SCN-Organic }}{\text { matter }} \\
\text { mater }\end{array}$ & opportunistic & $\begin{array}{l}\text { (Mekuto et } \\
\text { al., 2017; } \\
\text { Samal et al., } \\
\text { 2017) }\end{array}$ \\
\hline $\begin{array}{l}\text { Pseudomonas } \\
\text { sp. }\end{array}$ & $\begin{array}{l}\text { S2, s3, } \\
\text { S4 }\end{array}$ & $\begin{array}{l}\text { Biofilm, } \\
\text { Biosorption }\end{array}$ & $\begin{array}{c}\mathrm{Pb}+2, \mathrm{Ni}+2, \mathrm{Cu}+2, \mathrm{Cr} \\
+3, \mathrm{NO}_{3} \text {, detergents, } \\
\text { dyes, pesticides, } \\
\text { hydrocarbons }\end{array}$ & opportunistic & $\begin{array}{c}\text { (Naz et al., } \\
\text { 2016; } \\
\text { Ramadass et } \\
\text { al., 2018; } \\
\text { Roy et al., } \\
\text { 2018; Wasi } \\
\text { et al., 2013) }\end{array}$ \\
\hline $\begin{array}{c}\text { Acinetobacter } \\
\text { sp. }\end{array}$ & S2, S3 & & $\begin{array}{l}\text { Hydroxydioxane, Cr, } \\
\text { Clothianidin, cyprodinil, }\end{array}$ & yes & $\begin{array}{c}\text { (Chen et al., } \\
2018 ; \\
\text { Fernández et } \\
\text { al., 2018; } \\
\text { Wang et al., } \\
\text { 2019; Zhang } \\
\text { et al., 2017) }\end{array}$ \\
\hline Aeromonas sp. & S3 & $\begin{array}{l}\text { Biofilms - } \\
\text { Siderophores }\end{array}$ & $\begin{array}{l}\text { As, } \mathrm{Cu}, \mathrm{Fe}, \mathrm{Ni}, \mathrm{Zn}, \mathrm{Mn} \\
\text { (II), dyes, PHAs, }\end{array}$ & yes & $\begin{array}{c}\text { (Chen et al., } \\
\text { 2013; Du et } \\
\text { al., 2015; } \\
\text { Kumar et al., } \\
2016 ; \\
\text { Uhrynowski } \\
\text { et al., 2017; } \\
\text { Zhang et al., } \\
\text { 2019) }\end{array}$ \\
\hline Thauera sp. & S4 & & $\begin{array}{c}\mathrm{Zn}, \mathrm{Cd}, \mathrm{Co}, \mathrm{Cu}, \mathrm{Ni}, \mathrm{Pb}, \\
\text { Cr, Hg, Se }\end{array}$ & No & $\begin{array}{c}\text { (Fang et al., } \\
2018)\end{array}$ \\
\hline
\end{tabular}

